genes controlling major histocompatibility antigens, separated by a short distance in linkage group IX on chromosome 17 . One of these genes codes for the $\mathrm{H}-2^{\mathrm{k}}$ product and the other for the $\mathbf{H}-2^{d}$ product ; in addition to "private" specificities defined by specifically reacting antisera, the $\mathbf{H}-2$ gene products share certain "public" specificities defined by cross-reacting antisera. As previously suggested for the human HL-A genes, it is likely that the two $\mathbf{H}-2$ genes arose by duplication of a common precursor gene with subsequent mutation giving rise to private specificities. Separating the two loci for the $\mathrm{K}$ and $\mathrm{D}$ regions of $\mathrm{H}-2$ are genes $S s$ controlling serum $\alpha$-globulins and a group of $I r$ genes controlling immune responses to synthetic polypeptides and many other antigens, in the order $K, I r, S s, D$.

In several mammals certain Ir genes are olosely associated with major histocompatibility genes, and much evidence has been accumulated by $\operatorname{Dr} H$. McDevitt (Stanford School of Medicine) and others showing that these $I r$ genes exert their effects on thymusdependent $(T)$ lymphocytes. In some cases these genes also seem to affect reactions of B lymphocytes directly, but the evidence on this point is less compelling.

Marked differences in immune responses to other antigens are, however, associated with genetic control of the type of immunoglobulin synthesized by $B$ cells, quantitative differences in antibody formation, allotypes and idiotypes (the specific determinants of individual immunoglobulin molecules produced by clones of cells) all being related. This has been shown by, for example, Drs R. Krowther (New York), A. Nisonoff (University of Illinois) and M. Cohn (San Diego). Still other immune response genes are not obviously associated with major histocompatibility types or allotypes. This information, together with genetic and chemical observations on independent control of constant and variable regions of immunoglobulins, has greatly increased understanding of the genetic control of immune responsiveness in general.

The antigen-binding receptor at the surface of B lymphocytes is universally accepted to be an immunoglobulin, but the nature of the $T$ cell receptor for antigen remains elusive. Some groups of research workers, including Dr N. L. Warner (Melbourne), have presented evidence for the presence of immunoglobulin light chains and $\mu$ chains at the surface of $T$ lymphocytes, but most investigators have been unable to find immunoglobulins related to the membranes of $T$ cells, or inhibition of $T$ cell reactions by antisera against immunoglobulins. One view is that

$T$ cells have a non-immunoglobulin antigen-binding mechanism perhaps evolved from a primitive and widespread system of intercellular recognition. The relationships of the antigenrecognition system in $T$ cells, major histocompatibility antigens and linked Ir gene products are still obscure, and it seems likely that detailed chemistry will be required to resolve this problem.

Genetic differences in susceptibility to disease may be manifested primarily in the reactions of immunocompetent cells or at other levels. An example which was discussed in depth by $\mathrm{Dr}$ F. Lilly (New York) was the interaction of several genetically-controlled factors in determining the resistance or susceptibility of mice to virus leukaemogenesis. One of these factors is associated with $\mathrm{H}-2$ type, and may be attributable to $\operatorname{lr}$ genes. Relative differences in susceptibility of mice to lymphocytic choriomeningitis are also associated with H-2 type. But major genetic factors determine the ability of all cells from animals of a particular genotype to support virus replication, so that reactions of immunocompetent cells are not primarily involved in these cases. Several associations of human major histocompatibility antigens with particular diseases have come to light. These are difficult to interpret, as was emphasized by Professor W. F. Bodmer (University of Oxford) although their potential interest in eventually helping to reveal the genetic factors controlling

\title{
Rocks from the Rockall Plateau
}

Rocks scooped from the seabed of Rockall Bank are described in next Monday's issue of Nature Physical Science (June 19). They were obtained simply by hauling a dredge across the seabed and the collection includes many specimens which can be recognized as glacial erratics. But among the material are fragments which look as if they may have been broken off outcrops and may therefore give some indication of the composition of the Rockall Plateau itself. Three different types of rock are represented in this class and are described by E. J. W. Jones (University College, London), J. G. Mitchell (University of Newcastle), F. Shido (State University of New York at Albany) and J. D. Phillips (Woods Hole Oceanographic Institution).

The Rockall Plateau lies beneath the North Atlantic between Ireland and Iceland and is believed to be a piece of the jigsaw puzzle that was broken up when the North Atlantic was formed and North America moved away from Western Europe. The Rockall Plateau is thought to have immune responses in man is clear.

This conference was the last of a projected series of five at Brook Lodge organized and sponsored by the US National Institute of Allergy and Infectious Diseases. A new cycle of these immunology conferences, with European support, will begin in Italy in June 1973.

\section{TRANSLATION}

\section{Frameshift Mutations}

from our Cell Biology Correspondent

THE existence and properties of frameshift mutations, resulting from the deletion or insertion of a base from a gene, proved that the codons of the genetic code are triplets of bases. Once a frameshift mutation is introduced into a gene (for example, the insertion of an additional base) the reading frame is shifted so that all codons distal to the mutation are read out of phase unless, of course, a second and compensatory frameshift mutation (in this case, a deletion of a base) occurs to restore the phase and reading frame, or unless the particular bacterial strain also carries a frameshift suppressor mutation.

The existence of external frameshift suppressor mutations, analogous to ochre and amber suppressor mutations, was first noted by Riyasaty and Atkins in 1968, who hinted that altered transfer RNAs might be involved. Subsequently Yourno and Tanemura (1970)

gone with Greenland when Greenland was broken away from Europe in the Mesozoic, but later (during the early Tertiary) the plateau was also split from Greenland and became left behind as an isolated continental fragment submerged beneath the ocean, except for the tiny island of Rockall itself.

The three types of rock which have been recognized in the dredge haul are described as alkali olivine basalt, aegirine-riebeckite granite porphyry, and aegirine-riebeckite granite. Potassium-argon dating of samples of each rock type gives ages of about 54 million years (with the exception of the basalt which had an anomalously low age) which seem to be in accord with the beginning of the rifting which separated the Rockall Plateau from Greenland.

This is the first occasion that dredged rock samples from the Rockall Plateau have been dated, and the result is an indication of the igneous activity on the plateau presumably associated with the tensions occurring when the plateau was split from Greenland. 